\title{
Effect of Different Sowing Methods and Nitrogen Levels on Fodder Yield of Oat in Salt Affected Soil
}

\section{Muhammad Qaisar Nawaz}

\section{Soil Salinity Research Institute, Pindi Bhattian, Pakistan.}

\begin{abstract}
Scarcity of the feed and fodder availability in winter season has been considered as the foremost bottleneck in harnessing the potential of the livestock sector in Pakistan. In this perspective a field study was conducted for three consecutive years (2013 to 2015) at Soil Salinity Research Institute, PindiBhattian, Hafizabad, Pakistan to evaluate different nitrogen levels and the cost-effective sowing technique for oat forage production under salt affected conditions. Two sowing methods i.e. broad cast and drill sowing with 30 $\mathrm{cm}$ apart rows and four nitrogen levels $(75,100,125$ and $150 \%$ of $\mathrm{N}$ recommended dose i.e. $150 \mathrm{~kg}$ ha $)$ were tested. Recommended dose of PK fertilizer (85-60 PK kg ha ${ }^{-1}$ ) was used uniformly with experimental $\mathrm{N}$ rates. Data on plant height $(132.00 \mathrm{~cm})$, number of plants $\left(91.33 \mathrm{~m}^{-2}\right)$, number of tillers $\left(146.00 \mathrm{~m}^{-2)}\right.$, number of leaves tillers ${ }^{-1}(5.66)$, total dry matter $\left(17.70 \mathrm{tha}^{-1}\right)$ and fodder yield $\left(60.90 \mathrm{t} \mathrm{ha}^{-1}\right)$ showed that nitrogen application@150\% $\mathrm{N}$ of recommended dose with drill sowing proved to be the most cost effective technique for fodder oat production in salt affected soil as compared to other treatments.

Received | August 14, 2017; Accepted | October 12, 2017; Published | November 30, 2017

*Correspondence | Muhammad Qaisar Nawaz, Assistant Research Officer, Soil Salinity Research Institute Pindi Bhattian, Pakistan; Email: assoun_786@yahoo.com

Citation | Nawaz, M.Q.2017. Effect of different sowing methods and nitrogen levels on fodder yield of oat in salt affected soil. Pakistan Journal of Agricultural Research, 30(4): 323-328.

DOI | http://dx.doi.org/10.17582/journal.pjar/2017/30.4.323.328

Keywords | Sowing methods, N levels, Fodder oats, Salt affected soils
\end{abstract}

\section{Introduction}

$\mathrm{T}$ here is a great deficit in the current demand and supply of green fodder to feed rapidly expanding livestock industry in Pakistan. This dearth can be partially bridged by utilization of marginal lands through strengthening research and development activities in salt affected soils. Salinity drastically reduced the yield of nearly every conventional crop; so introducing non-conventional salt tolerant fodder crops might be a suitable option in salt affected soil. Cultivation of oats in winter season is worthwhile as it can provide green fodder for 60-70 days during lean periods when availability of fodder is scrimpy or negligible. Oat fodder is soft, palatable and rich in crude protein (10-12\%). According to Younis and Azam (2003), oat mixed with Berseem provides a balanced feed to milch animals. Furthermore, efficient nutrients management of oat crop might be helpful to improve the potential for producing high quality fodder (Mohr et al., 2004). The present scenario urged the agronomists to develop a comprehensive site specific agro technology to boost up fodder yield of oat in salt affected soils by improving some basic components of the prevailing oat production technology in Pakistan. Among various agro management factors, optimum level of nitrogen and sowing methods are of great importance to recognize maximum potential of oat in saline-sodic field. Nitrogen application assumes greater importance regarding the yield and quality of fodder (Fageria and Moreira, 2011). It is one of the most yield limiting plant nutrients under most 
agro ecological conditions and its efficient use is important for the economic sustainability of cropping systems (Fageria and Baligar, 2005). In fodder crops it is the most important input for forage production as the maximum vegetative growth is desired within a short period of time. Nitrogen performs a critical role in photosynthesis and is an indispensable part of protein. It is vital for physiological and enzymatic biochemical reactions in plant metabolism (Balasubramaniyan and Palaniappan, 2001). Consequently, it is quite impossible to think to achieve maximum potential of a crop without nitrogen application in salt affected soils. Optimum fertilization in salt affected soil resulted increased crop yields by improving nutrient contents in plant tissue and soil solution (Adediran et al., 2004) producing $67 \%$ more yield over control (Taiwo et al., 2001). So application rates of nitrogen that precisely match crop needs reduces the chances for nitrogen loss as it is readily taken up by established plant (Andraski et al., 2000).

Sowing techniques could also significantly affect the forage yield of fodder crop in salt affected soils. Photo accumulation rate and radiation use efficiency at different growth stages could be corrected by appropriate planting geometry and rows should be in the north-south direction which is the wind direction with maximum radiation interception (Beheshti et al., 2003). Considering above facts, a field experiments was carried out to increase fodder yield of oat with proper nutrient management under different sowing methods in salt affected soils.

\section{Materials and Methods}

An experiment was carried out at the research farm of Soil Salinity Research Institute, PindiBhattian, Hafizababd, Pakistan during winter season 2013 to 2015 to study the effect of different sowing methods (broad cast and drill sowing with $30 \mathrm{~cm}$ apart rows) and nitrogen levels [Recommended dose (150-85-60 NPK kg ha $\left.{ }^{-1}\right), 75 \% \mathrm{~N}$ of RD, $125 \% \mathrm{~N}$ of RD \& $150 \%$ $\mathrm{N}$ of $\mathrm{RD} \mathrm{kg} \mathrm{ha}{ }^{-1}$ ] on fodder yield of oat in salt affected soils. Soil samples were collected and analyzed for the selection of field before the start of study. A salt affected field with $\mathrm{pH}_{\mathrm{s}} 8.81, \mathrm{EC}_{\mathrm{e}}=4.29\left(\mathrm{dS} \mathrm{m}^{-1}\right)$ and $\mathrm{SAR}=36.50\left(\mathrm{mmol} \mathrm{L}^{-1}\right)^{1 / 2}$ was selected and well prepared for the sowing of oats crop. The experiment was laid out in split plot design with three replications. Sowing methods were kept in main plots and nitrogen levels in sub plots. Oat cultivar (S-2000) was sown using seed @ $75 \mathrm{~kg} \mathrm{ha}^{-1}$ in 3rd week of October. All $\mathrm{P}, \mathrm{K}$ and half $\mathrm{N}$ was applied at the time of sowing and remaining half $\mathrm{N}$ was applied at tillering stage in the forms of single super phosphate, sulphate of potash and urea respectively. All the standard agronomic management practices were adopted. The data regarding different agronomic parameters like plant height, number of plants $\mathrm{m}^{-2}$, number of tillers $\mathrm{m}^{-2}$,number of leaves tiller ${ }^{-1}$, total dry matter and fodder yield were recorded and subjected to analysis of variance according to Steel et al. (1997) to sort out significant differences among treatments means using LSD at $5 \%$ probability level. In order to assess the economic feasibility of different nitrogen levels and sowing methods, an economic analysis was evaluated (Shah et al., 2013).

Table 1: Effect of different nitrogen rates and sowing methods on plant height $(\mathrm{cm})$ of oat.

\begin{tabular}{llll} 
Nitrogen levels & \multicolumn{2}{l}{ Sowing methods } & Mean \\
& $\begin{array}{l}\text { Drill } \\
\text { Sowing }\end{array}$ & $\begin{array}{l}\text { Broadcast } \\
\text { Sowing }\end{array}$ & \\
Recommended dose (RD) & $110.00 \mathrm{~d}$ & $103.33 \mathrm{e}$ & $106.67 \mathrm{C}$ \\
$\begin{array}{l}150-85-60 \mathrm{NPK} \mathrm{kg} \mathrm{ha}{ }^{-1} \\
75 \% \mathrm{~N} \text { of RD }\end{array}$ & $108.33 \mathrm{~d}$ & $102.67 \mathrm{e}$ & $105.50 \mathrm{C}$ \\
$125 \% \mathrm{~N}$ of RD & $118.33 \mathrm{c}$ & $111.00 \mathrm{~d}$ & $114.67 \mathrm{~B}$ \\
$150 \% \mathrm{~N}$ of RD & $132.00 \mathrm{a}$ & $123.33 \mathrm{~b}$ & $127.67 \mathrm{~A}$ \\
Mean & $117.17 \mathrm{~A}$ & $110.08 \mathrm{~B}$ & -
\end{tabular}

LSD for Methods: 2.5810; LSD for Fertilizer: 3.3605; LSD for Interaction: 4.7601.

\section{Results and Discussion}

Pooled data of three years regarding plant height, showed linear response with increasing nitrogen levels, treatment using nitrogen @ 150\% of RD recorded the statistically $(\mathrm{P} \leq 0.05)$ maximum plant height $(127.67 \mathrm{~cm})$ which was followed by $125 \% \mathrm{~N}$ of $\mathrm{RD}$ with plant height of $(114.67 \mathrm{~cm})$ and minimum plantheight $(105.50 \mathrm{~cm})$ was observed where nitrogen was applied @ 75\% of RD and it was statistically at par with N@RD (Table 1). Sowing method also significantly influenced the plant height, drill sowing produced significantly taller plants $(117.17 \mathrm{~cm})$ than broadcast sowing $(110.08 \mathrm{~cm})$. Data regarding interactive effect of nitrogen levels and sowing method was also significant, which showed that nitrogen@150\% of $\mathrm{RD}$ with drill sowing produced maximum plant height of $(132.00 \mathrm{~cm})$ followed by broadcast sowing with nitrogen @ 150 \% of RD. Nitrogen is an important growth-limiting macro nutrient in salt affected 
soils Irshad et al. (2002). In our study this remarkable increased in plant height with application of $150 \% \mathrm{~N}$ of $\mathrm{RD}$ and planting geometry of $30 \mathrm{~cm}$ apart single row in drill sowing method may be ascribed to proper air circulation, efficient utilization of light and more area available to roots for nutrient acquisition as compared to broadcast method due to suppressive effect of forage oat and less photosynthetic activity because of poor light penetration (As mentioned by Afzal et al., 2013 as well). Comparable results have also been reported on fodder maize (Amin, 2011) and sorghum (Samia et al., 2010).

Table 2: Effect of different nitrogen rates and sowing methods on no. of plants $m^{-2}$ of oat.

\begin{tabular}{llll} 
Nitrogen levels & \multicolumn{2}{c}{ Sowing methods } & Mean \\
& $\begin{array}{l}\text { Drill } \\
\text { Sowing }\end{array}$ & $\begin{array}{l}\text { Broadcast } \\
\text { Sowing }\end{array}$ & \\
Recommended dose (RD) & $81.66 \mathrm{~cd}$ & $76.00 \mathrm{e}$ & $78.83 \mathrm{C}$ \\
150-85-60 NPK kg ha ${ }^{-1}$ & & & \\
$75 \% \mathrm{~N}$ of RD & $79.66 \mathrm{~cd}$ & $72.66 \mathrm{f}$ & $76.16 \mathrm{D}$ \\
$125 \% \mathrm{~N}$ of RD & $86.00 \mathrm{~b}$ & $79.33 \mathrm{~d}$ & $82.66 \mathrm{~B}$ \\
$150 \% \mathrm{~N}$ of RD & $91.33 \mathrm{a}$ & $81.66 \mathrm{c}$ & $86.50 \mathrm{~A}$ \\
Mean & $84.66 \mathrm{~A}$ & $77.41 \mathrm{~B}$ & -
\end{tabular}

LSD for Methods: 2.7001; LSD for Fertilizer: 1.4607; LSD for Interaction: 2.0611 .

Results depicted in Table 2 showed that there was a notable increase $(\mathrm{P} \leq 0.05)$ in number of plants $\mathrm{m}^{-2}$ with increasing levels of nitrogen. Sowing methods also showed pronounced effect, drill sowing proved superior (84.66 plants $\left.\mathrm{m}^{-2}\right)$ tobroadcast sowing (77.41 plants $\left.\mathrm{m}^{-2}\right)$. Pooled data reflected that maximum number of plants $\mathrm{m}^{-2}$ (86.50) were produced with $150 \% \mathrm{~N}$ of $\mathrm{RD}$ followed by $125 \% \mathrm{~N}$ of $\mathrm{RD}(82.66$ plants $\left.\mathrm{m}^{-2}\right)$. However, minimum number of plants $\mathrm{m}^{-2}$ (76.16) were recorded where nitrogen was applied @ 75\% N of RD. Interactive effect of nitrogen levels and sowing methods $(\mathrm{N} \times \mathrm{S})$ also showed significant effect on plant population. Greater plant population $\mathrm{m}^{-2}$ was (91.33) recorded where nitrogen was applied @ $150 \%$ of RD followed by $125 \% \mathrm{~N}$ of $\mathrm{RD}(86.00$ plants $\mathrm{m}^{-2}$ ) with drill sowing. Significant increase in plant population with $150 \% \mathrm{~N}$ of $\mathrm{RD}$ in drill sowing might be attributed to efficient utilization of nutrients and availability of sufficient amount of light and water etc. in a comparatively larger net area for off shoot production (Awan et al., 2011). Varying nitrogen level with different plant densities also gave significant results in forage sorghum (Bahrani and Ghenateghestani, 2004). Similar results of nitrogen levels have also been reported by Ayub et al. (2010; 2011) for sorghum, and cluster bean crops which reinforced the findings of this study.

Data regarding the number of tillers $\mathrm{m}^{-2}$ (Table 3) showed that nitrogen levels, sowing methods and their interactive effect significantly $(P \leq 0.05)$ increased number of tillers $\mathrm{m}^{-2}$. Over all mean value of three years illustrated that highest number of tillers $\mathrm{m}^{-2} 140.17$ were recorded in $150 \% \mathrm{~N}$ of $\mathrm{RD}$ which was statistically non-significant with $125 \% \mathrm{~N}$ of $\mathrm{RD}$ where mean tillers were $138.67 \mathrm{~m}^{-2}$. Similarly, drill sowing produced the maximum number of tillers $\mathrm{m}^{-2}$ (138.75) when compared with broadcast method recording tillers $\mathrm{m}^{-2}$ as 127.83 . Interactive effect of sowing methods and nitrogen levels was also found significant. Nitrogen applied @ $150 \%$ of RD produced more number of tillers $\mathrm{m}^{-2}(146.00)$ which was statistically non-significant with $125 \% \mathrm{~N}$ of RD giving 144.67 tillers $\mathrm{m}^{-2}$ in drill sowing. Increase tillering with higher level of nitrogen in drill sowing may be on account of good crop stand under saline conditions and higher availability of nitrogen which enhanced the growth because getting good stand of plants is a preliminary success in using salt affected soils. A positive effect of nitrogen on number of tillers has been also reported earlier (Nyalemegbe et al., 2012).

\section{Table 3: Effect of different nitrogen rates and sowing} methods on No. of tillers/ $m^{2}$ of oat.

\begin{tabular}{llll} 
Nitrogen levels & \multicolumn{2}{c}{ Sowing methods } & Mean \\
& $\begin{array}{l}\text { Drill sow- } \\
\text { ing }\end{array}$ & $\begin{array}{l}\text { Broadcast } \\
\text { sowing }\end{array}$ & \\
Recommended dose (RD) & $136.67 \mathrm{~b}$ & $125.00 \mathrm{~d}$ & $130.83 \mathrm{~B}$ \\
$\begin{array}{l}150-85-60 \mathrm{NPK} \mathrm{kg} \mathrm{ha}{ }^{-1} \\
75 \% \mathrm{~N} \text { of RD }\end{array}$ & $127.67 \mathrm{~d}$ & $119.33 \mathrm{e}$ & $123.50 \mathrm{C}$ \\
$125 \% \mathrm{~N}$ of RD & $144.67 \mathrm{a}$ & $132.67 \mathrm{c}$ & $138.67 \mathrm{~A}$ \\
$150 \% \mathrm{~N}$ of RD & $146.00 \mathrm{a}$ & $134.33 \mathrm{bc}$ & $140.17 \mathrm{~A}$ \\
Mean & $138.75 \mathrm{~A}$ & $127.83 \mathrm{~B}$ &
\end{tabular}

LSD for Methods: 0.9405; LSD for Fertilizer: 3.1201; LSD for Interaction: 4.4102 .

As far as number of leaves tiller $^{-1}$ are concerned, pooled data of three consecutive seasons, showed pronounced effect of increasing levels of nitrogen on number of leaves tiller ${ }^{-1}$. Treatment receiving nitrogen @ 150\% of RD recorded the peak value of number of leaves (5.00) followed by $125 \% \mathrm{~N}$ of RD producing leaves tiller ${ }^{-1} 4.66$. Results also reflected that drill sowing produced more number of leaves tiller ${ }^{-1} 4.75$ which was at par with broadcast sowing i.e. 3.75 leaves 
tiller $^{-1}$. Data regarding interactive effect of nitrogen levels and sowing method showed that nitrogen applied@150\% of RD produced maximum number of leaves till ${ }^{-1}$ i.e. 5.66 which was statistically alike with nitrogen@125\% of $\mathrm{RD}$ i.e. 5.00 leaves tiller ${ }^{-1}$ with drill sowing and it was also statistically at par with nitrogen applied @ 150 and 125\% of RD with broadcast sowing producing the same number of leaves tiller $^{-1}$ i.e. 4.33. With efficient nitrogen management, the plants remained green for a longer period which results in more contribution of carbohydrates from current photosynthates (Subha et al., 2004). Increase in number of leaves and leaf area plant ${ }^{-1}$ with nitrogen application has also been reported by Gasim (2001), Akram et al. (2010), Khalid et al. (2010) and Amin (2011).

Table 4: Effect of different nitrogen rates and sowing methods on No. of leaves/tiller of oat crop under saline conditions.

\begin{tabular}{llll} 
Nitrogen levels & \multicolumn{2}{c}{$\begin{array}{c}\text { Sowing methods } \\
\text { Drill sowing Broadcast }\end{array}$} & Mean \\
& \multicolumn{3}{c}{$\begin{array}{c}\text { sowing } \\
\text { Recommended dose (RD) }\end{array}$} \\
$\begin{array}{llll}\text { 150-85-60 NPK kg ha }{ }^{-1} \\
\text { scd }\end{array}$ & $3.33 \mathrm{~d}$ & $3.83 \mathrm{~B}$ \\
$75 \% \mathrm{~N}$ of RD & $4.00 \mathrm{~cd}$ & $3.00 \mathrm{~d}$ & $3.50 \mathrm{~B}$ \\
$125 \% \mathrm{~N}$ of RD & $5.00 \mathrm{ab}$ & $4.33 \mathrm{abc}$ & $4.66 \mathrm{~A}$ \\
$150 \% \mathrm{~N}$ of RD & $5.66 \mathrm{a}$ & $4.33 \mathrm{abc}$ & $5.00 \mathrm{~A}$ \\
Mean & $4.75(\mathrm{NS})$ & $3.75 \mathrm{NS})$ &
\end{tabular}

LSD for Methods: 1.2400; LSD for Fertilizer: 0.6605; LSD for Interaction: 0.9306 .

Green fodder yield depicted in Table 5 revealed significant differences among the nitrogen levels and sowing methods. Nitrogen applied @ 150\% of RD was the most effective treatment in increasing fodder $\left(59.36\right.$ t.ha $\left.^{-1}\right)$ and differed significantly from $125 \% \mathrm{~N}$ of $\mathrm{RD}$ with fodder yield of $\left(57.11 \mathrm{t}^{\mathrm{h}} \mathrm{ha}^{-1}\right)$ while lowest value of fodder yield (48.41 t.ha $\left.{ }^{-1}\right)$ was recorded where nitrogen was applied @ 75\% of RD. With respect to sowing methods, drill sowing has better effect on fodder yield $\left(56.39\right.$ t.ha $\left.^{-1}\right)$ as compared to broadcasting (53.08 t.ha- $\mathrm{h}^{-1}$ ). Interaction of nitrogen levels and sowing method indicated the highest fodder yield (60.90 t.ha ${ }^{-1}$ ) with nitrogen @ $150 \%$ of RD followed by nitrogen @ $125 \%$ of RD (58.75 t.ha $\left.{ }^{-1}\right)$ with drill sowing whereas minimum fodder yield was produced when $75 \% \mathrm{~N}$ of $\mathrm{RD}$ was applied with broadcast sowing $\left(46.50\right.$ t.ha $\left.^{-1}\right)$. Increase in forage yield with increased nitrogen doses (150\% and $125 \% \mathrm{~N}$ of $\mathrm{RD}$ ) may be attributed to the fact that nitrogen performs a critical role in increasing vegetative growth of crops and each individual plant in drill sowing enjoyed uniform supply of nitrogen and other essential nutrient due to ample availability of light, space, and aeration and also the advantage of less severe competition as in broadcast sowing, which leads higher deposition of photosynthates in the crop plant. Our outcomes are in consistence with findings of Olanite et al. (2010) and Khalid et al. (2010) who reported that higher level of nitrogen contributed to progressive increase in bio mass of the crop plant.

Table 5: Effect of different nitrogen rates and sowing methods on green fodder yield $\left(t . h a^{-1}\right)$ of oat.

\begin{tabular}{llll} 
Nitrogen levels & \multicolumn{2}{c}{ Sowing methods } & Mean \\
& $\begin{array}{l}\text { Drill } \\
\text { sowing }\end{array}$ & $\begin{array}{l}\text { Broadcast } \\
\text { sowing }\end{array}$ & \\
Recommended dose (RD) & $55.60 \mathrm{~d}$ & $52.50 \mathrm{e}$ & $54.05 \mathrm{C}$ \\
$150-85-60 \mathrm{NPK} \mathrm{kg} \mathrm{ha}{ }^{-1}$ & & & \\
$75 \% \mathrm{~N}$ of RD & $50.33 \mathrm{f}$ & $46.50 \mathrm{~g}$ & $48.41 \mathrm{D}$ \\
$125 \% \mathrm{~N}$ of RD & $58.73 \mathrm{~b}$ & $55.50 \mathrm{~d}$ & $57.11 \mathrm{~B}$ \\
$150 \% \mathrm{~N}$ of RD & $60.90 \mathrm{a}$ & $57.83 \mathrm{c}$ & $59.36 \mathrm{~A}$ \\
Mean & $56.39 \mathrm{~A}$ & $53.08 \mathrm{~B}$ &
\end{tabular}

LSD for Methods: 0.1510; LSD for Fertilizer: 0.4608; LSD for Interaction: 0.6609 .

Table 6: Effect of different nitrogen rates and sowing methods on dry matter yield ( $\left.t . h a^{-1}\right)$ of oat.

\begin{tabular}{llll} 
Nitrogen levels & \multicolumn{2}{l}{ Sowing methods } & Mean \\
& $\begin{array}{l}\text { Drill sow- } \\
\text { ing }\end{array}$ & $\begin{array}{l}\text { Broadcast } \\
\text { sowing }\end{array}$ & \\
Recommended dose (RD) & $15.43 \mathrm{~b}$ & $14.26 \mathrm{c}$ & $14.85 \mathrm{C}$ \\
$150-85-60 \mathrm{NPK} \mathrm{kg} \mathrm{ha-1}$ & & & \\
$75 \% \mathrm{~N}$ of RD & $14.70 \mathrm{bc}$ & $14.03 \mathrm{c}$ & $14.36 \mathrm{C}$ \\
$125 \% \mathrm{~N}$ of RD & $17.33 \mathrm{a}$ & $15.43 \mathrm{~b}$ & $16.38 \mathrm{~B}$ \\
$150 \% \mathrm{~N}$ of RD & $17.70 \mathrm{a}$ & $16.93 \mathrm{a}$ & $17.31 \mathrm{~A}$ \\
Mean & $16.29 \mathrm{~A}$ & $15.16 \mathrm{~B}$ &
\end{tabular}

LSD for Methods: 0.3705; LSD for Fertilizer: 0.6503; LSD for Interaction: 0.9204 .

Data of dry matter yield (Table 6) revealed that the effect of nitrogen increment and sowing method on dry matter yield was statistically $(\mathrm{P} \leq 0.05)$ significant. Results showed that nitrogen applied @ 150\% of $\mathrm{RD}$ produced maximum dry matter yield (17.31 t.ha $\left.{ }^{1}\right)$ which was statistically different from $125 \% \mathrm{~N}$ of $\mathrm{RD}\left(16.38 \mathrm{t} \cdot \mathrm{ha}^{-1}\right)$. Minimum dry matter $\left(14.36 \mathrm{t} \mathrm{ha}^{-1}\right)$ was produced in $75 \% \mathrm{~N}$ of $\mathrm{RD}$ which was at par with recommended dose $\left(14.85 \mathrm{t} \mathrm{ha}^{-1}\right)$. In case of sowing methods; maximum dry matter $\left(16.29\right.$ t.ha $\left.^{-1}\right)$ was 
Table 7: Effect of different nitrogen rates and sowing methods on net income and benefit: cost ratio (BCR) of oat crop.

Nitrogen levels

\section{Drill sowing}

Cost of production (Rs.)

Recommended dose (RD) 168000

150-85-60 NPK kg ha-1

$75 \% \mathrm{~N}$ of $\mathrm{RD}$

$125 \% \mathrm{~N}$ of $\mathrm{RD}$

$150 \% \mathrm{~N}$ of $\mathrm{RD}$
162000

174000

177000

\section{Sowing methods}

\section{Broadcast sowing}

Benefit: Cost of pro- Gross in- Net in- Benefit: duction (Rs.) come (Rs.) come (Rs.) Cost

come (Rs.) come (Rs.) Cost

1.985714165900

315000

149100

1.898734

$1.864074 \quad 162900$

279000

116100

1.712707

$2.025172 \quad 174900$

333000

158100

1.903945

$2.064407 \quad 177900$

169080

1.950422 recorded in drill sowing which differed significantly from broad cast sowing with dry matter production of $15.16 \mathrm{t}^{\text {.ha }} \mathrm{a}^{-1}$. Interactive effect of nitrogen levels and sowing methods showed that nitrogen applied@150\% of $\mathrm{RD}$ with drill sowing recorded the highest value of dry matter $\left(17.70\right.$ t.ha $\left.^{-1}\right)$. However, statistically no significant difference was found among N @ $125 \%$ of $\mathrm{RD}$ in drill sowing (17.33 t.ha-1) and N @ $150 \%$ of $\mathrm{RD}$ in broad cast sowing $\left(16.93\right.$ t.ha $\left.^{-1}\right)$. The increase in green fodder and dry matter yield with higher rate of nitrogen can be ascribed to increase in plant height, number of leaves per plant and stem diameter of oat. These results substantiate findings of Rasheed et al. (2005) they reported that nitrogen and sulphur application at the rate of $150+30$ and $150+20 \mathrm{~kg} \mathrm{ha}^{-1}$ greatly increased the dry weight per plant over control.

Economic feasibility in financial terms of any innovation or technique has primary importance in deciding its wider adoption among farming community (Khan et al., 2012). Economic analysis was carried out at the end of study to evaluate the best, economical nitrogen level and sowing technique to grow oat fodder crop under salt affected conditions. Two sowing technique and three nitrogen levels resulted in different net income as presented in the Table 7. Data regarding economic analysis for treatments revealed that the highest net income was earned with nitrogen application @ 150\% of RD in drill sowing (Rs.188400 ha ${ }^{-1}$ ) as compare to other treatments which may be due to more economic yield.

This study concluded that maximum plant population, number of tillers, higher number of leaves and higher fodder yield were found with nitrogen application@ @150\% of recommended dosein drill sowing as compared to broadcast sowing.

\section{Author's Contribution}

Muhammad Qaisar Nawaz conceived the idea, an- alysed the data, wrote the article and did overall management of the article. Khalil Ahmed wrote abstract. Syed Saqlain Hussain and Muhammad Qaisar Nawaz did data collection and entry in SPSS. Khalil Ahmed, Muhammad Sarfraz, Muhammad Rizwan, Ghulam Mustafa Wains and Muhammad Jamil provided technical Input at every step.

\section{References}

Adediran, 2004. Application of organic and inorganic fertilizer for sustainable maize and cowpea yields in Nigeria. J. P1. Nut. 27(7):11631181.

Afzal, M., A.U.H. Ahmad, S.I. Zamir, F. Khalid, A.U. Mohsin and S.M.W. Gillani. 2013. Performance of multicut forage sorghum under various sowing methods and nitrogen application rates. J. Anim. Plant Sci. 23(1): 232-239.

Akram, M., M.Y. Ashraf, E.A. Waraich, M. Hussain and A.R. Mallahil. 2010. Performance of autumn planted maize (Zea mays L.) hybrids at various nitrogen levels under salt affected soils. Soil Environ. 29(1): 23-32.

Amin, M. and El-Murtada Hassan. 2011. Effect of different nitrogen sources on growth, yield and quality of fodder maize (Zea mays L.). J. Saudi Soc. Agric. Sci. 10: 17-23. https://doi. org/10.1016/j.jssas.2010.06.003

Andraski, T.W., L.G. Bundy and K.R. Brye. 2000. Crop management and corn nitrogen rate effects on nitrate leaching. J. Environ. Qual. 29: 1095-1103. https://doi.org/10.2134/ jeq2000.00472425002900040009x

Awan, T.H., R.I. Ali, Z. Manzoor, M. Ahmad and M. Akhtar. 2011. Effect of different nitrogen levels and row spacing on the performance of newly evolved medium grain rice variety, KSK133. J. Anim. P1. Sci. 21(2): 231-234.

Ayub, M., M. Khalid, M. Tariq, M.A. Nadeem and M. Naeem. 2011. Effect of different seeding 
densities and nitrogen levels on growth, forage yield and quality attributes of cluster bean $(C y-$ amoposistetragonolobaTuab.). J. Agric. Technol. 7:1409-1416.

Ayub, M., M.A. Nadeem, A. Tanvir and A. Husnain. 2002. Effect of different levels of nitrogen and harvesting times on the growth, yield and quality of sorghum fodder. Asian J. P1. Sci. 4: 304-307.

Ayub, M., M.A. Nadeem, M. Tahir, A. Ghafoor , Z. Ahmed and M. Naeem. 2010. Comparative studies on the growth, forage yield and quality of sorghum (Sorghum bicolor L.) varieties under irrigated conditions of Faisalabad. Pak. J. life Soc. Sci. 8: 94-97.

Bahrani, M.J. and A.D. Ghenateghestani. 2004. Summer forage sorghum yield, protein and prussic acid contents as affected by plant densityand nitrogen top dressing. J. Agric. Sci. Tech. 6(1/2): 73-83.

Balasubramaniyan, P. and S.P. Palaniappan. 2001. Nutrient management. In: Principles and practices of agronomy. Agrobios, India. pp.185-188.

Beheshti, A., A. Koocheki and M.N. Mahalati. 2003. The effect of planting pattern on light interception and radiation use efficiency in canopy of three maize cultivars. Seed Plant. 18(4): 417-431.

Fageria, N.K. and A. Moreira. 2011. The role of mineral nutrition on root growth of crop plants. Adv. Agron. 110: 251-331. https://doi. org/10.1016/B978-0-12-385531-2.00004-9

Fageria, N.K. and V.C. Baligar. 2005. Enhancing nitrogen use efficiency in crop plants. Adv. Agron.88: 97-185. https://doi.org/10.1016/ S0065-2113(05)88004-6

Gasim, S.H. 2001. Effect of nitrogen, phosphorus and seed rate on growth, yield and quality of forage maize (Zea mays L.). M.Sc. Thesis, Faculty of Agric., Univ. of Khartoum, Sudan .

Irshad, M., S. Yamamoto, A.E.T. Endo and T. Honna. 2002. Urea and manure effect on growth and mineral contents of maize under saline conditions. J. Plant Nut. 25:189-200. https:// doi.org/10.1081/PLN-100108790

Khalid, M., I. Ahmad and M. Ayub. 2010. Effect of nitrogen and phosphorus on the fodder yield and quality of two sorghum cultivars (Sorghum bicolor L). Int. J. Agric. Biol. 5(1):61-63.

Khan, M.B., M. Khan, M. Hussain, M. Farooq, K. Jabran and D.J. Lee. 2012. Bio-economic assessment of different wheat-canola intercrop- ping systems. Int. J. Agric. Biol. 14: 769-774.

Marschner, H. 1995. Mineral nutrition of higher plants, $2^{\text {nd }} E d$. Academic press. San Diego.

Mohr, R.M., C.A. Grant and W.E. May. 2004. Nitrogen, Phosphorus, and Potassium fertilizer management for oats. Better Crops. 88 (4): 12-14.

Nyalemegbe, K.K., S.A. Brempong and S.K.A. Danso. 2012. Evaluation of SesbaniasesbanL. (Merr) and Mimosa invisaL. (Fabaceae) as sources of nitrogen in irrigated rice on the vertisols of the Accra Plains of Ghana. J. Eco. Natural Environ. 4(3): 88-93. https://doi.org/10.5897/ JENE11.102

Olanite, J.A., U.Y. Anele, O.M. Arigbede, A.O. Jolaosho and O.S. Onifade. 2010. Effect of plant spacing and nitrogen fertilizer levels on the growth, dry-matter yield and nutritive quality of Columbus grass (Sorghum almumstapf) in southwest Nigeria. Grass Forage Sci. 65(4): 369-375. https://doi.org/10.1111/j.13652494.2010.00755.x

Rasheed, M., H. Ali and T. Mahmood. 2005. Impact of nitrogen and sulfur application on growth and yield of maize (Zea Mays L.) crop. J. Res. Sci. 15: 153-157.

Samia, O., Yagoub and A.K. Abdelsalam. 2010. Effect of nitrogen and seed rates on growth and yield of forage sorghum (Sorghum bicolor L moenchcv. abusabien). J. Sci. Technol. 11: 123-136.

Shah, M.A., A. Manaf, M. Hussain, S. Farooq and M. Zafar-ul-Hye. 2013. Sulphur fertilization improves the sesame productivity and economic returns under rainfed conditions. Int. J. Agric. Biol. 15: 1301-1306. (Be uniform)

Steel, R.G.D., J.H. Torrie and D.A. Dickey. 1997. Principles and Procedures of Statistic: A Biometrical Approach. 3rd edition, pp: 400 - 428. Mc Graw Hill book Co. Inc. New York.

Subha, K.M., B. Chandrasekaran, P. Parasuraman, S.D. Sivakumar, K. Rubapathi and K. Chozhan. 2004. Performance of scented rice variety Basmati 370 under organic farming. Madras Agric. J. 91(7-12): 353-358.

Taiwo, L.B., J.A. Adediran, M.O. Akando, V.A. Banjoko and G.A. Oluwatosin. 2001. Influence of legume fallow on soil properties and yield of maize in South Western Nigeria. J. Agric. Trop. Subtrop. 102(2): 109-117.

Younis, M. and M.Azam. 2003. Response of different levels of $\mathrm{N}$ and $\mathrm{P}$ on the forage yield of oat. Pak. J. soil Sci. 22 (2): 64-66. 